\title{
Hydroclimatic relationships with planktonic time series from 1975 to 1992 in the North Sea off Gravelines, France
}

\author{
Geneviève Le Fevre-Lehoerff ${ }^{1, *}$, Frédéric Ibanez ${ }^{2}$, Paola Poniz ${ }^{2}$, \\ Jean-Marc Fromentin ${ }^{2}$ \\ ${ }^{1}$ IFREMER Centre de Brest, BP 70, F-29280 Plouzané, France \\ ${ }^{2}$ Observatoire Océanologique, Station Zoologique, BP 28, F-06230 Villefranche-sur-Mer, France
}

\begin{abstract}
Planktonic time series collected since 1975 off Gravelines, France, were analysed in the context of climatic changes. Principal component analysis and the cumulative sums method were applied to 30 data sets which included meteorological and hydrological parameters and planktonic descriptors. Eight groups of biological descriptors were linked to external parameters. The study of winds highlighted the importance of cyclonic and anticyclonic influences. Seven year cycles appeared clearly in air temperature and in species abundance with different trophic levels for species such as Temora longicornis, Oikopleura dioica and Sagitta setosa, whereas an 11 yr cycle appeared for Pseudocalanus minutus. A 3 to 4 yr cycle was detected for atmospheric pressure, precipitation and some species. This cycle may or may not be superimposed on another (for example, on an 11 yr cycle).
\end{abstract}

KEY WORDS: Time series $\cdot$ Zooplankton $\cdot$ Meteorology Hydrology $\cdot$ Southern North Sea

\section{INTRODUCTION}

At the turn of the century, British researchers had already set up a system for climatic and biological monitoring on a regular basis for the North Atlantic, Channel and North Sea regions, such as the E1 station located in Plymouth, England, followed by a series of CPR (Continuous Plankton Recorder) measurements. These enabled long-term fluctuations to be monitored (Russell 1935) and then summarised to highlight the links between climatic changes (Lamb 1969, 1985) and biological changes in terms of fish stocks, plankton and the intertidal benthos (Cushing 1961, 1978, Southward 1963, Russell et al. 1971, Cushing \& Dickson 1976). The periodic phenomena described as the 'Russell Cycle' are still referred to today. Since plankton recorders have remained in operation, various simple or complex mathematical processing methods have enabled assessment of the results and comparisons to be drawn

\footnotetext{
•E-mail: genevieve.lehoerff@ifremer.fr
}

(Colebrook 1981, 1982, Colebrook \& Taylor 1984. Ibanez 1984, Ibanez \& Etienne 1992, Fromentin et al. 1993, Ibanez et al. 1993).

The plankton record from Gravelines, France, presented here covers part of the chronological data gathered from 1975 onwards. The study was begun following the decision to build a high-power (5500 MW) coastal nuclear power plant. The objective was first to assess site characteristics (e.g. hydrology, microbiology, plankton, fish, benthos) before the plant was put into operation (1980) and then to monitor its impact. The plankton data were used to study seasonal species variations (Toularastel et al. 1977, Le Fèvre-Lehoerff \& Quintin 1981, Woehrling \& Le Fèvre-Lehoerff 1993), for the impact study (Le Fèvre-Lehoerff \& Woehrling 1991, Le Fèvre-Lehoerff et al. 1993b) and for spatial comparison between Gravelines and other Channel sites (Le Fèvre-Lehoerff et al. 1983, 1993a). The data used within the context of regional climatic changes (Fromentin \& Ibanez 1994) concern only the area outside of the power plant's impact area. 


\section{MATERIALS AND METHODS}

Sampling area. Gravelines is located between Calais and Dunkerque (Fig 1) in the southern part of the North Sea on a low, sandy coastline. Semi-diurnal alternating tidal currents run parallel to the coastline and the general residual current flows toward the North Sea. Coastal counter-currents are exceptional, and can divert water from large northern European rivers (e.g. the Escaut, Belgium) southwards. Irregular flows of $350000 \mathrm{~m}^{3} \mathrm{~d}^{-1}$ issue from a small canalised river in France called the Aa.

Sampling irequency. The sampling approach adopted was determined by the geographical situation and research objectives. The first aspect was a multidisciplinary approach during sampling surveys. The second involved an assessment of the environment's natural variability by replicate samples and samples taken during tidal cycles. Man-made constructions implemented from 1973 to 1980 modified the shoreline, and consequently, our research strategy. From 1980 on, impact studies based on spatial comparisons rather than on time-based variations (Chardy \& Menesguen 1984) were mainly used in this research.

Surveys were conducted between September 1974 and October 1986 at a rate of 10 to 12 times $\mathrm{yr}^{-1}$ Their number then dropped to $3 \mathrm{yr}^{-1}$ Since measurements are less accurate offshore, weekly measurements were taken at the entrance to the plant. Few measurement points were used here. The non-impacted zone succes-

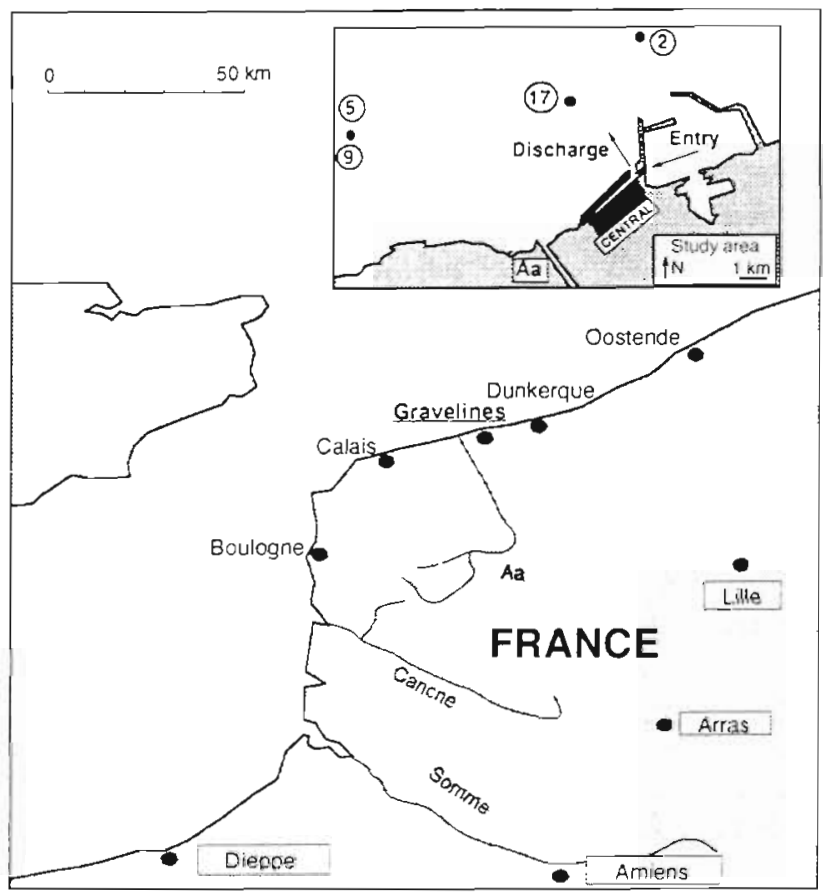

Fig. 1. Geographical zone of study sively shifted on a geographical scale. This does not appear to be of great importance, considering the movement of water masses with the tide

All measurements are included in 1 file list: Points 9 and 17 from September 1974 to December 1975, Point 2 from August 1976 to May 1978 and from April 1982 to September 1993, and Point 5 from August 1976 to February 1982 (Fig. 1)

Measurement techniques. Conventional oceanographic techniques (Aminot \& Chaussepied 1983) were applied in field studies and laboratory analyses. The more specific techniques employed are described in a collective publication (Belsher et al. 1986). Samples were collected using Niskin bottles and a WP2 plankton net $(200 \mu \mathrm{m})$. Hydrologically speaking, the shallow water ( 20 to $25 \mathrm{~m}$ ) only required samples taken at a few levels (3) and for vertical tows of zooplankton. The filtered volume was evaluated using a TSK flowmeter attached to the net opening (Le Fèvre-Lehoerff 1985). To estimate the suspended matter (SM) in the sea water, samples were filtered through a precombusted $0.45 \mu \mathrm{m}$. Whatman filter. The samples of SM, nutrients, chlorophyll and zooplankton biomass were frozen as soon as possible after being collected. The zooplankton samples which were to be used for counting and determination of species were put in formalin ( $8 \%$ final concentration). Nutrients were analysed using a Technicon Autoanalyser and expressed in mmol $\mathrm{l}^{-1}$ for each nutrient, $\mathrm{NO}_{3}^{-}, \mathrm{NO}_{2}^{-}$, $\mathrm{NH}_{4}^{+}, \mathrm{PO}_{4}^{-}, \mathrm{SiOH}^{-}$. The chlorophyll biomass was assessed using a fluorometer and expressed in $\mathrm{mg} \mathrm{m}^{-3}$ The zooplankton biomass was dried for $48 \mathrm{~h}$ at $60^{\circ} \mathrm{C}$, weighed $\left(\mathrm{mg} \mathrm{m}^{-3}\right)$, then homogenised and analysed with a Carlo Erba elemental analyser; results were given as carbon and nitrogen percentages of dry weight. Densities (no. $\mathrm{m}^{-3}$ ) were estimated for the species determined.

Data. Meteorological parameters: The following parameters were available: air temperature, atmospheric pressure, precipitation, number of days with east and west winds. Readings of monthly values were recorded in Dunkerque from January 1974 to December 1992, except for wind, which was measured from 1976 onward

Hydrological parameters: Conservative hydrological parameters such as water temperature $\left({ }^{\circ} \mathrm{C}\right)$ and salinity (PSU) were available for the period 1976 to 1992. Other non-conservative parameters such as nitrogen salts $\mathrm{NO}_{3}{ }^{-}, \mathrm{NO}_{2}^{-}, \mathrm{NH}_{4}{ }^{+}$(from 1976 to 1988) as well as $\mathrm{PO}_{4}$ and $\mathrm{SiOH}^{-}$(from 1976 to 1986) were expressed in mmol $\mathrm{l}^{-1}$. Overall parameters were estimated for SM (from 1976 to 1986) in $\mathrm{mg} \mathrm{l}^{-1}$, chlorophyll $\left(\mathrm{mg} \mathrm{l}^{-1}\right.$ ) from 1976 to 1992, phaeopigments ( $\mathrm{mg} \mathrm{l}^{-1}$ ) $(1978,1986)$, and zooplankton biomass in dry weight ( $\mathrm{mg} \mathrm{m}^{-3}$ ) from 1976 to 1992 . 
Biological descriptors: The total zooplankton species present at Gravelines comprised approximately 150 taxa (Le Fèvre-Lehoerff et al. 1976). This inventory was drawn up at the start of the study; subsequently only about 40 taxa were regularly counted. This selection also supplied the 14 biological descriptors (Table 1) used in the analysis. These species were well represented in terms of frequency and number of individuals. Other abundant species were rejected because their presence was too erratic. Many observations were lacking for the time series (110 monthly sampled values out of 220). This was especially true for later years, when sampling dropped to 4 times in 1986, then to 2 in 1989. Abundance data were log-transformed in order to stabilise the variance. To render the data more regular, median observation values within each month were used (sampling unit: $1 \mathrm{mo}$ ).

Numerical analyses. Cumulative sums: Chronological series in oceanography often contain missing values. In spite of this it is important to detect the general trend in order to compare biological and environmental conditions. Toward this aim the simple method of the cumulated function (Ibanez et al. 1993), which does not require special conditions, can be applied. For a chronological series with data $x_{t}$ sampled for each $t(t$ varying between 1 and $n$ ), a reference value $k$ is chosen (which could be e.g. the mean of the series, or an indicative value). After subtracting $k$ from each data point, the residuals are added successively.

$$
S_{p}=\sum_{i=1}^{p} x_{i}-p k
$$

For successive values equal to $k$, the curve will be horizontal, and for successive values lower than $k$, the slope will be negative, and vice versa.

If an erratic, high value exists (large peak or dip), this will also show up as a marked anomaly on the curve of cumulative sums. However, small fluctuations are smoothed.

For information purposes, Bravais-Pearson correlations were calculated using series of cumulative sums. The $\mathrm{r}$ significance value for 100 degrees of freedom was 0.19 at the $5 \%$ threshold and 0.25 at the $1 \%$ threshold. However, this conventional test could not be used since the terms of cumulative sums are autocorrelated. An extremely scrupulous approach would have included a Monte Carlo simulation producing an $r$ value distribution. However, this would have been excessive since the cited correlations taken for our research were all considerably higher than the previous statistical thresholds.

Principal component analysis (PCA): An analysis was conducted by principal components, using the series of cumulative sums from the 14 biological
Table 1. Mean, standard deviation, maximum (all in ind. per $10 \mathrm{~m}^{3}$ ) and percentage of zero (\%) in counted categories

\begin{tabular}{|lrrrr|}
\hline Category & Mean & SD & Max. & $\%$ \\
\hline Sagitta setosa (SAGI) & 65 & 277 & 3687 & 11 \\
Lanice conchilega (LANI) & 256 & 1079 & 10625 & 3 \\
Pleurobrachia pileus (PLEU) & 7 & 27 & 229 & 16 \\
Paracalanus parvus (PARA) & 292 & 899 & 7476 & 1 \\
Pseudocalanus minutus (PSEU) & 424 & 1347 & 11565 & 3 \\
Centropages hamatus (CENT) & 1890 & 9417 & 129090 & 1 \\
Temora longicornis (TEMO) & 6324 & 19433 & 163158 & 0 \\
Cyphonaut larvae bryozoa (CYPH) & 184 & 763 & 8853 & 2 \\
Cirriped nauplii (CINA) & 172 & 564 & 6382 & 3 \\
Cirriped cypris (CICY) & 140 & 776 & 11625 & 8 \\
Acartia clausi (ACAR) & 1544 & 4817 & 46010 & 0 \\
Euterpina acutifrons (EUTE) & 686 & 6504 & 112960 & 5 \\
Oncaea sp. (ONCA) & 122 & 625 & 9674 & 4 \\
Oikopleura dioica (OIKO) & 897 & 2728 & 22116 & 2 \\
\hline
\end{tabular}

descriptors. The 11 hydrological parameters were entered as supplementary variables. Correlations with the first 3 components graphically displayed the proximities of the 25 variables (Dauvin \& Ibanez 1986).

\section{RESULTS}

\section{Year-to-year changes in meteorological and hydrological parameters}

\section{Meteorological parameters}

Air temperature at Dunkerque (Fig. 2a) showed various phases of trends over several years: stable oscillation from 1974 to 1980 , followed by a slight rise from 1980 to 1984 . The recent drop in temperature, characterised by cold winters from 1985 to 1987 and the rise in temperatures after 1987, are meteorological events which correspond to periodicities highlighted in studies of data from the last 50 yr (1949 to 1992), and particularly to $7-8$ yr cycles (Fromentin \& Ibanez 1994).

Atmospheric pressure (Fig. 2b) showed a very smooth profile from 1974 to 1986 and an overall decreasing trend, except for the anomaly of the 1976 anticyclonic period. Following a period of relative stability from 1986 to 1989 , an increasing trend was seen up to 1992 . Study of the last 50 yr revealed a significant 32 mo cycle.

Precipitation (Fig. 2c) also presented a major cycle lasting $64 \mathrm{mo}$. A 32 mo harmonic cycle is detected if all observations over the last half century are taken into account. Anomalies can be seen for the period 1974 to 1992, with high winter rainfall $(1977,1982,1988)$ and summer drought (1976 and at the end of the series), to which a long-term, increasing trend observed between 1978 and 1984 should be added. 

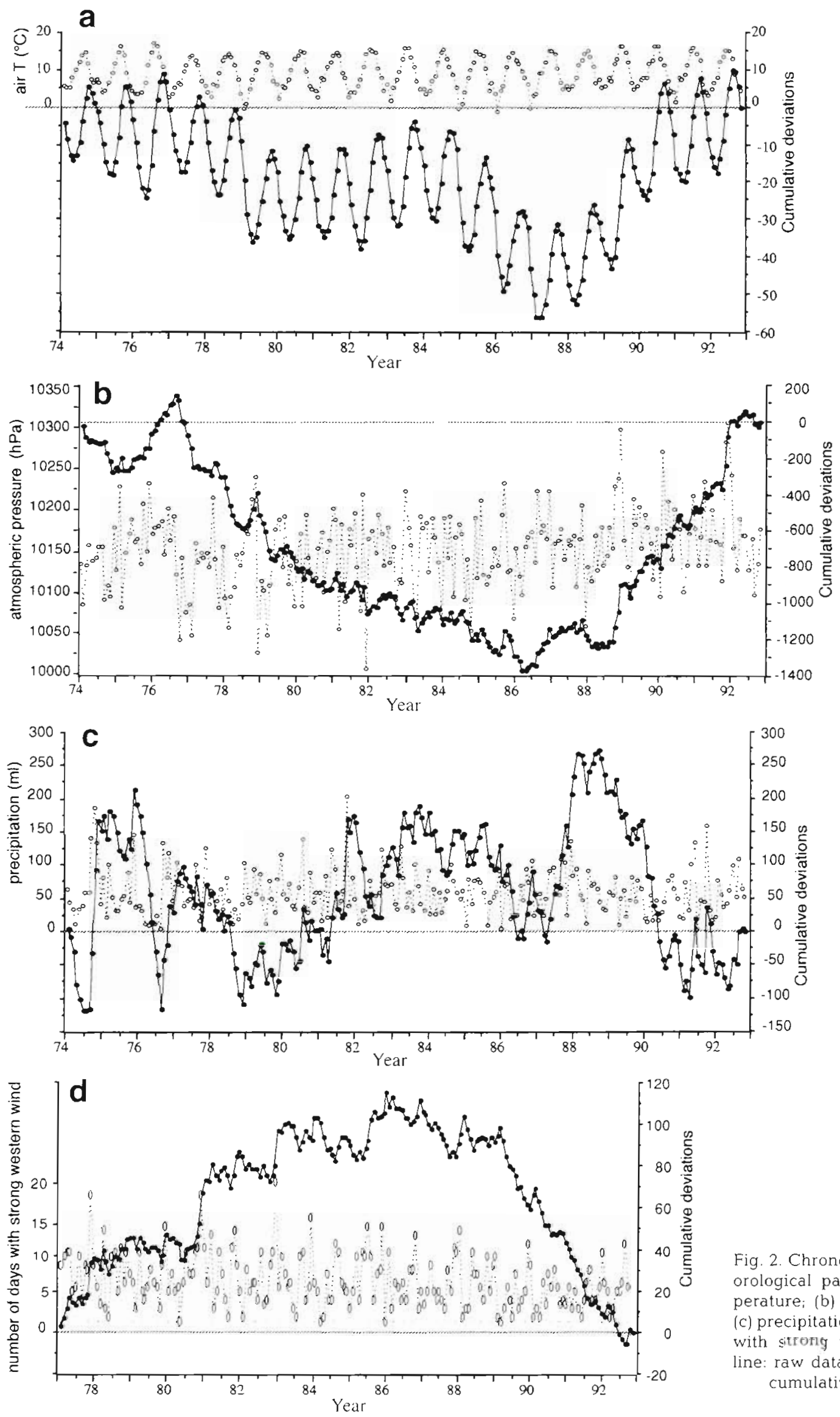

Fig. 2. Chronological series of meteorological parameters: (a) air temperature; (b) atmosphenc pressure; (c) precipitations; (d) number of days with strong western wind. Dotted line: raw data; solid line: data after cumulative sums treatment 
East winds were estimated as no. of days $\mathrm{mo}^{-1}$ with winds over $7 \mathrm{~m} \mathrm{~s}^{-1}$ (following recommendations set out by Lagadeuc 1992). Two periods of instability appeared in 1979 and 1986, when decreasing trend was observed. A characteristic anticyclonic condition period was seen in 1988-1992. West winds (Fig. 2d) from the sea are generally stronger than east winds; they tended to increase until 1986, followed by a decrease.

For information purposes, correlations between parameters were calculated from the cumulative sums. These correlations were all highly significant (with the reservation that observations were not independently performed). Overall, the results were largely coherent. High temperatures $\left(T_{\text {aIr }}\right.$, in $\left.{ }^{\circ} \mathrm{C}\right)$ and anticyclonic conditions coincided with high atmospheric pressure (atm $\mathrm{P}$ ) $\left(\mathrm{T}_{\text {aii }} /\right.$ atm $\left.\mathrm{P}, \mathrm{r}=0.911^{\circ}\right)$, high precipitation and low atmospheric pressure are correlated $(\mathrm{r}=-0.595 *)$ and correlated with west winds (atm P/west winds, $r=$ $-0.845 \cdots)$

\section{Conservative hydrological parameters}

Water temperature ( $\mathrm{T}_{\text {water }}$ ) (Fig. 3a) during the yearly cycle fluctuated between $5^{\circ} \mathrm{C}$ in January and $18.8^{\circ} \mathrm{C}$ in August (mean monthly temperatures calculated for the period 1975 to 1991). The general annual mean temperature was $11.27^{\circ} \mathrm{C}$ (Le Fèvre-Lehoerff \& Woehrling 1991). The cumulative sums of water temperature trace a U-shaped curve; this movement reflects the influence of climatic processes in Dunkerque, especially those of air temperature and atmospheric pressure. Thus calculated correlations for $\mathrm{T}_{\text {air }} / \mathrm{T}_{\text {water }}(\mathrm{r}=0.941 \cdots)$ and $\mathrm{atm} \mathrm{P} / \mathrm{T}_{\text {water }}(\mathrm{r}=0.876 \cdots)$ were noted. From 1976 onward, the series showed a decreasing trend, reversing to a general warming trend from 1986 onward.

Fig. 3b presents the salinity (S) variations. Mean $\mathrm{S}$ ranged from 33.63 PSU yearly to 32.96 PSU for March and 34.08 PSU for September. Although seasonal variations occasionally show correlations between temperature and salinity, long-term series are more difficult to understand, as the correlation coefficient is calculated on the cumulative sums $(\mathrm{T} / \mathrm{S}=0.4 \cdots)$. High and low $\mathrm{S}$ anomalies and general variations result from the combined action of general circulation phenomena, evaporation, precipitation, thermal flux, wind force and direction (Dickson 1971, Taylor et al. 1981, Maddock \& Pingree 1982, Taylor \& Stevens 1983). The curve of cumulative sums reflected high values at the beginning and end of the series. This tallies with results from other authors who noted high $\mathrm{S}$ values in the Channel and the North Sea in recent years (Becker et al. 1992). The causal factors in this research, as in the studies previously mentioned, were not yet demonstrated, nor was a relation with wind direction. The only suggested relation is that of low $\mathrm{S}$ in water coming from all the coastal and northern European rivers along with north winds which could push these waters against the coastline (Salomon \& Breton 1993). The only coherent results observed were the coincidence, in the middle of the period studied, of an increasing trend for precipitation and a decreasing trend for salinity.

\section{Non-conservative chemical parameters}

At Gravelines, very high values were seen for nutrient salt concentrations; over $20 \mathrm{mmol} \mathrm{l}^{-1}$ of $\mathrm{NO}_{3}^{-}$and over $10 \mathrm{mmol} \mathrm{l}^{-1}$ of $\mathrm{SiOH}^{-}$for a winter monthly mean calculated for the period 1975 to 1991 (Le FèvreLehoerff et al, 1993a). On cumulative sum curves, yearly cycles can be recognised, conventionally with maxima in winter. Over the entire period studied, there were 2 notable peaks in 1979 and 1983, 4 yr apart. This was the case for all nutrients (Fig. 3d, e, f). This phenomenon may be related to circulation in the southern North Sea, especially the coastal counter-currents coming from the large northern European rivers, since large declines in salinity and low winter temperatures were also observed during these periods. Correlations were calculated between nutrients and water temperature: $\mathrm{NO}_{3} / \mathrm{T}_{\text {water, }} \mathrm{r}=-0.819^{\circ}$. Correlations between different nutrients were strong: $\mathrm{NO}_{3} / \mathrm{SiOH}$, $r=0.552^{*}$

\section{Overall parameters}

Chlorophyll values were high, reaching 10 to $40 \mathrm{mg}$ $\mathrm{I}^{-1}$ in spring, depending on the year. In Fig. 3c, seasonal variations are easily recognised. For the period 1976 to 1989 , the cumulative sum curve followed, overall, the changes in water temperature. Phaeopigments developed quite similarly. Correlations were calculated on the cumulative values chl $a / T_{\text {water, }} r=0.806 *$ and chl a/phaeopigments, $\mathrm{r}=0.798^{\circ}$. Although the yearly cycle showed increased values for spring, when the water was still cool, long-term changes appeared to indicate another phenomenon. The positive combined action on chlorophyll in the warmest years, anticyclonic periods, and good periods of sunshine were certainly favourable factors (at the end of the period, after 1985).

SM followed the same trend as seen for nitrates, with 2 marked reversals, one in 1980 and the other in 1983, giving maximum values on the cumulative sum curves. Over the entire period studied, the increases mentioned were most likely linked to the same phenome- 


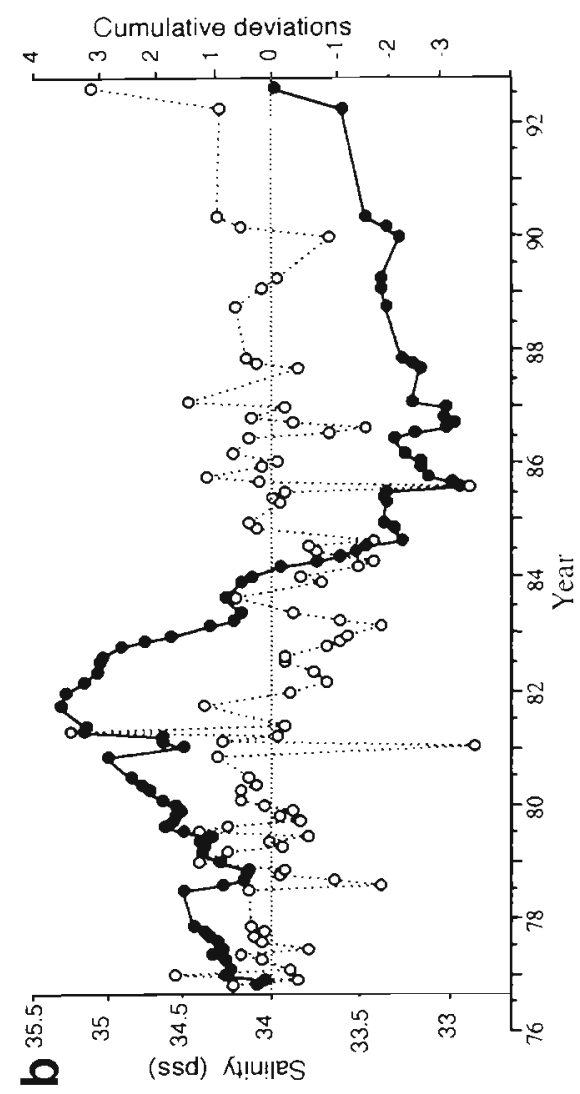

Cumulative deviations

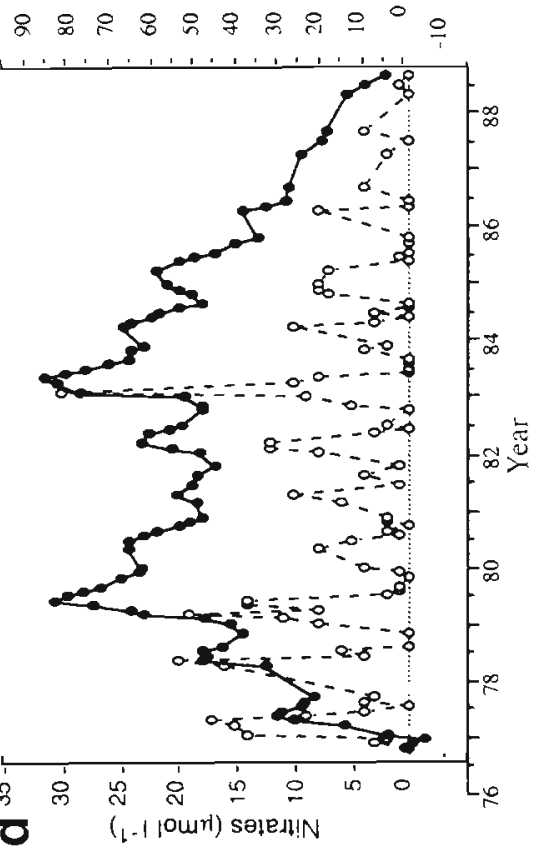

o ( - - lowri) seled!n

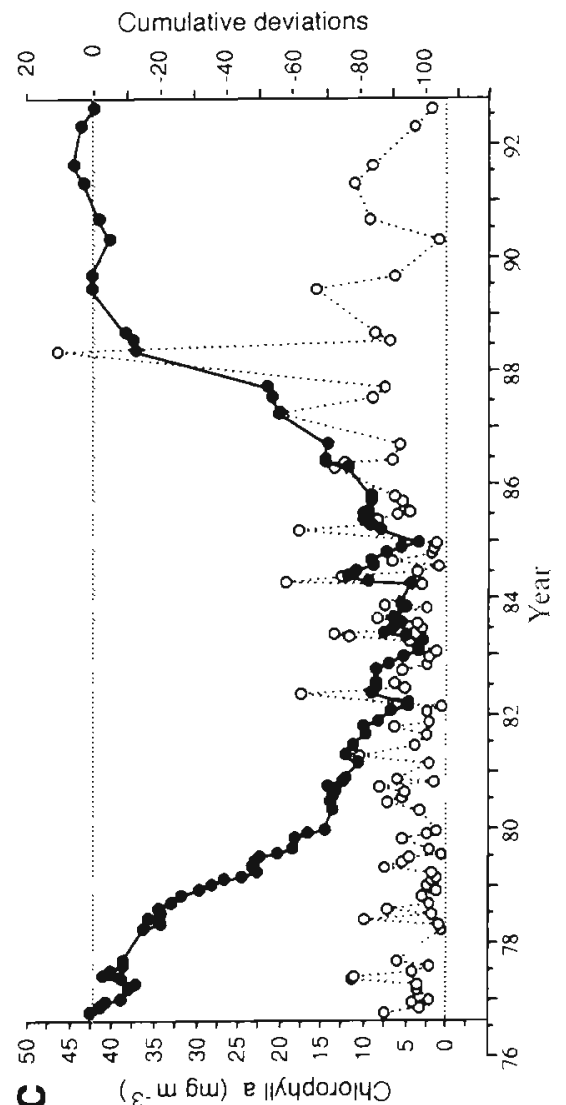

c
Cumulative deviations

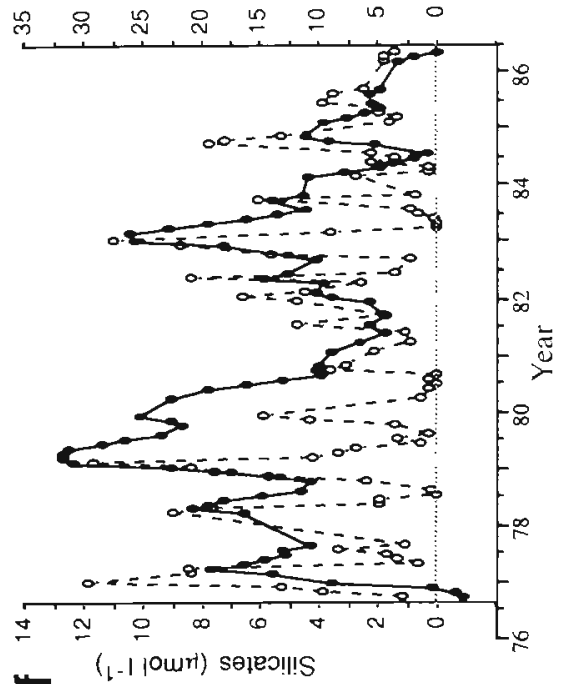

— ( (-1 lour ) seleo!!!S

Cumulative deviations

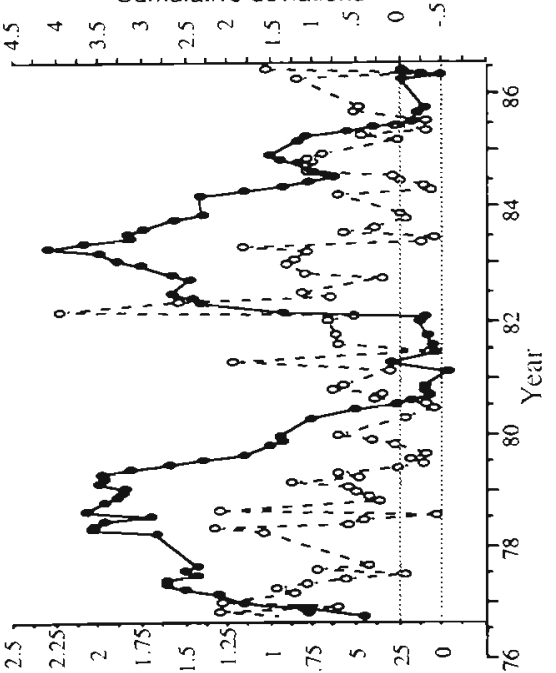

() (1.1 10url) seleydsoud

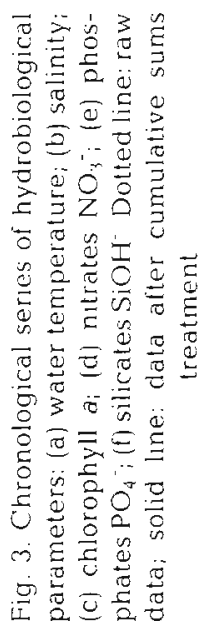

ก $\cong \subseteq \pm \cong$

(⿻)

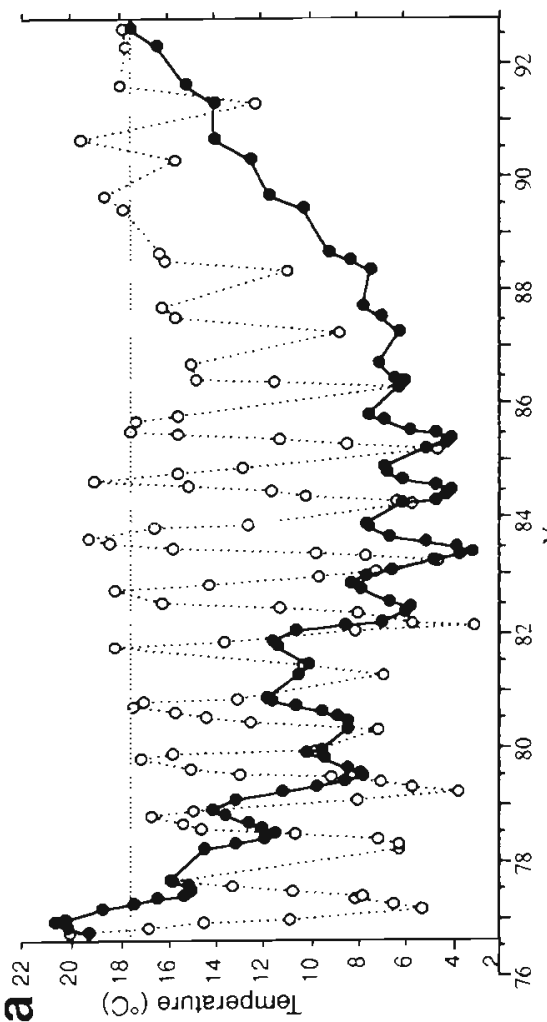


non of southern North Sea water circulation already mentioned for nutrient salt variations.

\section{Biological descriptors}

Results of PCA

PCA was done using 14 biological descriptors, with hydroclimatic parameters introduced as complementary variables (Fig. 4). All variables were studied as cumulative sums.

By plotting ordinates on the 3 mean axes, it was possible to determine 8 groups of biological descriptors, by classification. In order to interpret changes over time, only 1 key category from each group is described here. These were chosen on the basis of the strongest link with a hydrological parameter. All changes over time for the other descriptors of the group were very similar to those of the key category.

The following 8 groups were used:

H1: Oikopleura dioica, Temora longicornis; $\mathrm{H} 2$ : Pseudocalanus minutus, Oncaea sp.; H3: cirriped cypris larvae, Centropages hamatus, Lanice conchilega;

H4: Euterpina acutifrons;

H5: cirriped nauplii larvae;

H6: Bryozoa cyphonaut larvae, Pleurobrachia pileus, Acartia clausi;

H7: Paracalanus parvus;

H8: Sagitta setosa.

Axis 1 very clearly indicates the opposition between atmospheric pressure, air and water temperatures and chlorophyll (positive correlations) and precipitation, along with west winds, dominant winds and nitrates (negative correlations). Therefore, it represents the opposition between periods of stability and instability. The greatest variability appears to be due to meteorological conditions. The organisms which stability most favoured were Temora longicornis and Oikopleura dioica (H1) whereas those most favoured by instability were Pseudocalanus minutus, Oncaea sp. ( $\mathrm{H} 2)$ and Paracalanus parvus $(\mathrm{H} 7)$.

Axis 2 demonstrates the influence of typical hydrological characteristics on population changes over time. High values of salinity correlate positively on Axis 2, as opposed to precipitation. The cirriped
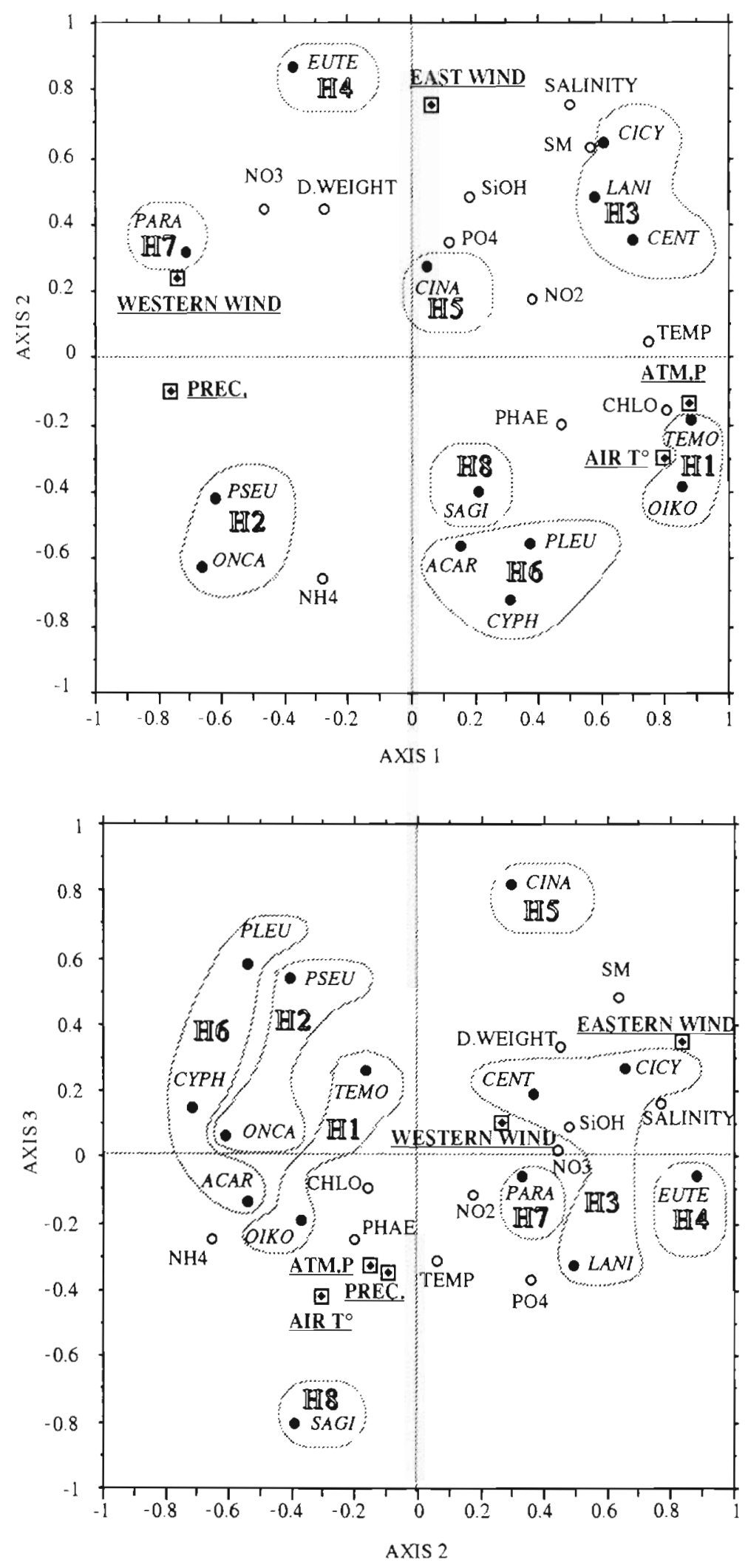

Fig. 4. Principal component analysis results conducted with meteorological, hydrological parameters and 14 biological descriptors. Codes as in Table 1 

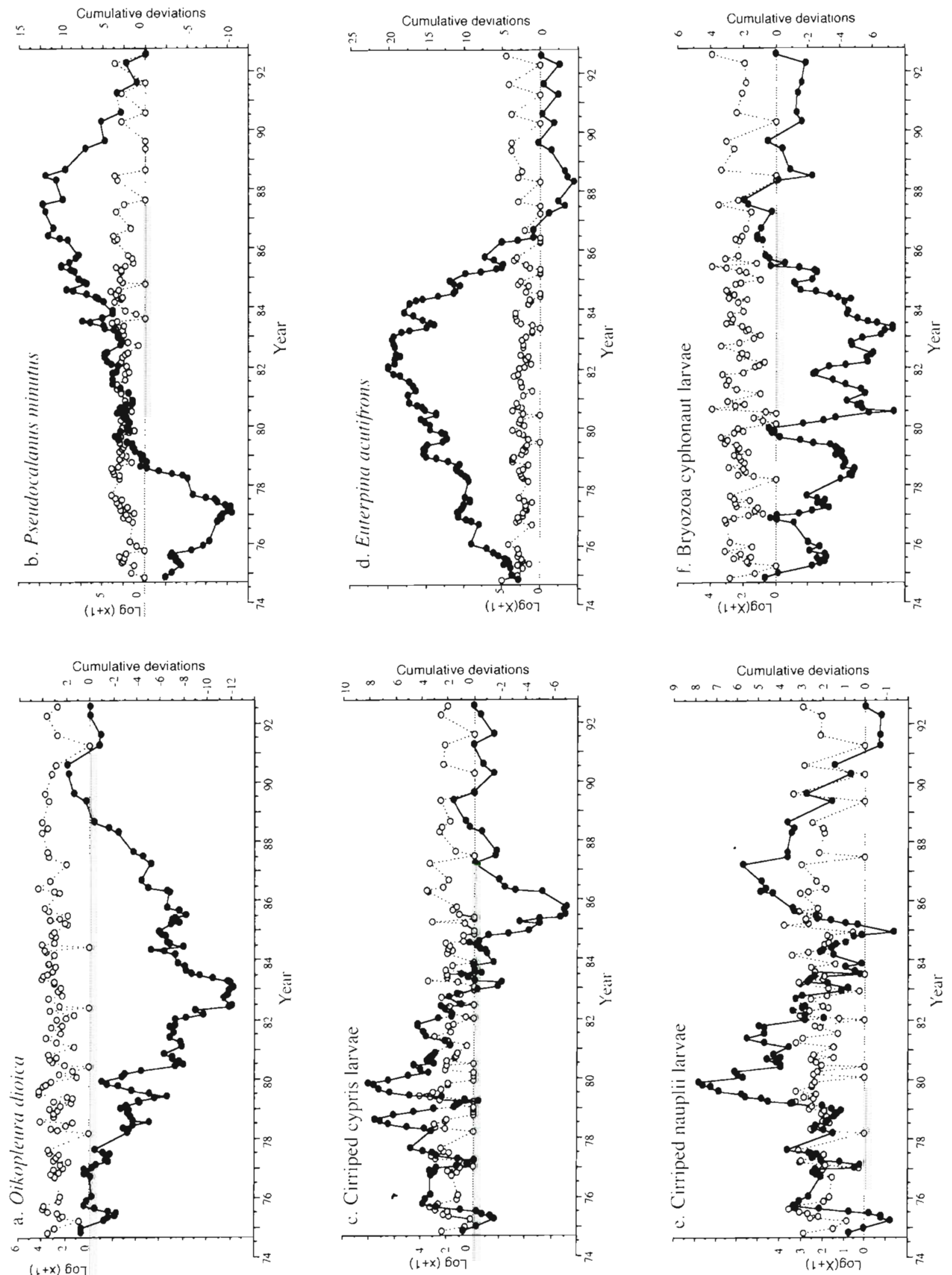


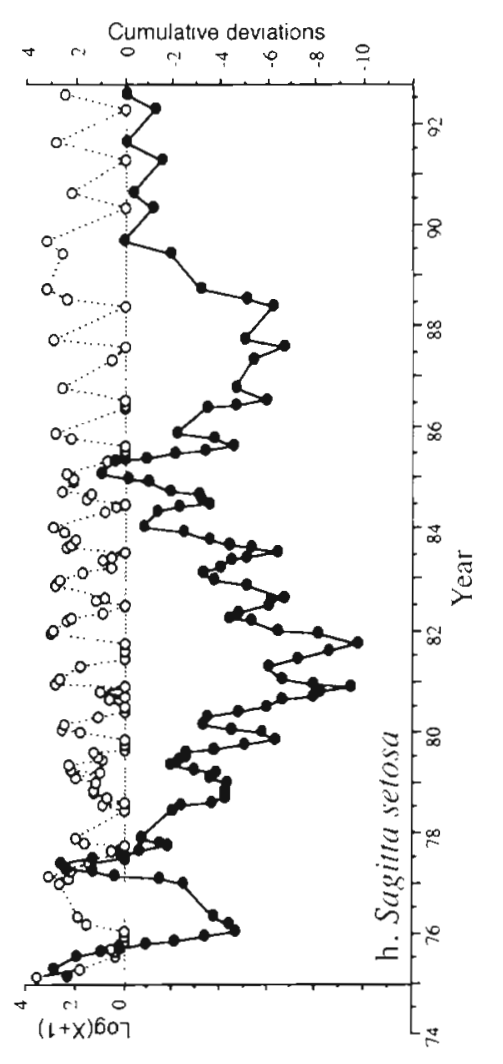

cypris larvae, Lanice conchilega and Centropages hamatus ( $\mathrm{H} 3)$ were strongly linked to episodic high temperatures and salinity, with east winds, whereas the most abundant species in low salinity water situations were those from groups $\mathrm{H} 2$ and H6: Pseudocalanus minutus, Oncaea sp., and Bryozoa cyphonaut larvae, Pleurobrachia pileus, and Acartia clausi.

Axis 3 shows how great an effect biological variables have and highlights the opposition between various groups. For instance, the opposition between cirriped nauplii (H5) and chaetognaths Sagitta setosa (H8) is clearly seen.

\section{Changes in biological descriptors over time}

Group H1: Oikopleura dioica (Fig. 5a) is one of the coastal appendicularians, a food source for flat fish on sandy bottoms (Wyatt 1973). They can reach sizes which represent $20 \%$ of zooplankton dry weight. Thanks to its 'house' system, this animal filters phytoplankton and fine organic particles. At Gravelines, a high correlation was seen (correlations calculated on a yearly cycle) with high temperatures: $r=0.800^{\circ}$ and large amounts of phytoplankton (Toularastel et al. 1977). The seasonal variation can be easily identified at the start of the series. On the curve of cumulative sums 3 clearly recognizable periods can be distinguished. An overall view of the 7 yr cycle is also provided. There are very sharp positive slopes at the end of 1979 , in early 1983 and in spring 1986 . These peaks follow nitrate values, with a 3 to 5 mo lag. On the cumulative sum curves, a highly significant correlation is seen with chlorophyll $\left(\mathrm{r}=0.87{ }^{\prime} \cdot\right)$ with temperature $\left(\mathrm{r}=0.763^{\circ}\right)$ and a negative correlation with respect to nitrate $\left(r=-0.646^{*}\right)$.

The copepod Temora longicornis can reach a population level of $10^{4}$ ind. $\mathrm{m}^{-3}$ and make up $80 \%$ of zooplankton abundance in spring. The seasonal variation is easily seen, as for Oikopleura dioica. The correlations calculated on cumulative sums are strongly linked to food (phytoplankton, represented schematically by chlorophyll).

Therefore, the H1 group represented by Oikopleura dioica and Temora longicornis was distinguished by species favoured by chlorophyll-rich waters, according to the herbivore food index. The 7 yr cycle was easily recognised for this group and correlations between Temora and Oikopleura were strong, $\mathrm{r}=0.638^{\circ}$

Group H2: For Pseudocalanus minutus (Fig. 5b) the cumulative sums showed very clear trends: from 1974 to 1977, a decreasing trend; between 1977 and 1988, marked population growth, especially in 1979 and 1986. From 1988 on, a decreasing trend was observed. The parallel with temperature changes is obvious. The 
trend showed a continuous growth gradient over 11 yr from 1977 to 1988. By presenting long time series of $P$. minutus and other species from 1948 to 1980 . Colebrook highlighted the possibility of detecting several combined cycles at the same time: 3 to $4 \mathrm{yr}, 5$ to $6 \mathrm{yr}$ and 11 yr cycles (Colebrook 1986) and the persistence of a species stock from year to year (Colebrook 1981, Colebrook \& Taylor 1984). This recurring phenomenon can be seen in planktonic populations as well as in benthic ones. For the Oncaea species in the same group, the relation to temperature was not as strong; however, it was very strong with low salinity. Thus the H2 group, represented by both $P$. minutus and Oncaea sp. copepods, featured an affinity with low salinity, low temperature and could easily withstand a low chlorophyll content in the water. An 11 yr cycle with 3 to 4 yr fluctuations was evident. The 2 copepods which represent this group are considered to be omnivorous. Their capability of adapting to various food forms, ranging from large phytoplankton cells to small flagellates (Smetacek 1985) or even living or non-living matter in variable proportions depending on the season (Poulet 1973, 1974, 1976), enhances their dominance over other species for living in winter periods in cold water, sometimes with low primary production in the North Sea and the North Atlantic

Group H3: The cirriped cypris (Fig. 5c) are not naturally abundant on sandy coasts, but their larvae can colonise man-made structures such as seawalls and industrial or harbour installations. At the Gravelines site, chlorine is injected into the power plant's pumped sea water cooling circuits to limit proliferation of cirriped populations (and other fouling groups such as the bryozoa, molluscs and hydrozoa). Therefore, changes in larval abundance at the nauplii and cypris stages were closely monitored. Cypris larvae (Fig. 5c) showed very high seasonal variability owing to their life span; however, the year-to-year changes were far from random. The evolution precisely followed that of salinity, with a very high correlation $\left(r=0.751^{\cdots}\right)$. Salinity may well be a limiting factor for this larval stage, or at the least, its influence may be greater than that of the environment's nutrient resources. The correlations which were calculated between taxa in the same group were $r=0.622 \cdots$ for cypris/Centropages and $r=0.676 *$ for cypris/Lanice. Lanice are sand-dwelling annelids generally abundant in low salinity waters, and large numbers of them are carried to Gravelines by the north European rivers (J. M. Dewarumez pers. comm.). Thus, in the first analysis, it may seem curious that the curve of cumulative sums revealed a positive relation with salinity. The long-term phenomenon must take longterm changes in salinity into account over a wider scale as well as the effect on benthic populations from either salinity (Dickson et al. 1988) or temperature anomalies, particularly in winter, which can have a recurrent effect on benthic populations (Beukema 1989). For larvae groups, fluctuations also depend on all conditions encountered during their long pelagic life (Marcaco 1990) and buoyancy characteristics of aulophore larva (Bhaud \& Cazaux 1990). Summer periods are favourable for keeping larvae on the surface, both for cypris (Le Fèvre \& Bourget 1991) and for Lanice, and the combined effect of high temperature and high salinity cannot be distinguished $\left(\mathrm{r}=0.541^{*}\right)$. The Centropages hamatus copepod was favoured by increases in temperature, salinity and chlorophyll (Centropages/ $\mathrm{T}_{\text {water }}, \mathrm{r}=0.509^{\cdots}$ ).

Group H4 (Fig. 5d): The harpacticoid copepod Euterpina acutifrons produces many generations per year in its seasonal cycle and its development time is linked to short-term temperature fluctuations (Bernard 1963, Haq 1972). At Gravelines, maximal abundance in the seasonal cycle is seen in late summer. The geographical distribution of $E$. acutifrons is vast, ranging from the North Sea to the Mediterranean and the Black Sea. It is an omnivorous, even carnivorous feeder. On the cumulative sum curves (Fig. 5d) 3 rather distinct periods can be seen, with a reverse in trends in 1983. The calculated correlations give positive values with nitrates and salinity and negative values with chlorophyll ( $\mathrm{r}=$ $\left.-0.545^{\cdots}\right)$. The ecological characteristics mentioned above agree with these results. It can be observed that this carnivore's reaction was opposite to that of the herbivore Oikopleura dioica, and slope changes appeared in 1979, 1983 and 1986, as for nitrates. (Euterpina/ $\mathrm{NO}_{3}$, $\mathrm{r}=0.652 \cdots$ ). It could be interesting to compare the $\mathrm{H} 4$ group represented by Euterpina acutifrons in a subsequent study. Seeing its wide geographical distribution, this could be one of the species enabling long-term changes in general climatic factors to be compared over a large geographical area.

Group H5: Cirripeda nauplii. Considering the extreme variety in the category (Fig. 5e) which is comprised of many very small larvae in early cirriped stages and distributed in swarms, the general population curve is quite similar to noise. Only the seasonal alternation due to the disappearance of this young stage can be recognised. The same was not true for the cumulative sum curve where a 7 yr cycle could clearly be distinguished. This periodicity was already revealed in the year-to-year evolution of meteorological parameters represented by air temperature. The relation with $T_{a i r}$ was negative $(r=-0.306 *)$. Relations to salinity $\left(r=0.468^{\circ}\right)$ and suspended matter $\left(r=0.591^{*}\right)$ were calculated.

Group H6: Bryozoa cyphonauts (Fig. 5f). For this group, which also includes the ctenarian Pleurobrachia and the copepod Acartia clausi, neither a clear cycle nor a period could be determined on the series. High 
growth periods were noted in 1983 and 1987, along with a relationship with low salinity, although correlations were rather low.

Group H7: Paracalanus parvus (Fig. $5 g$ ) is a copepod with a wide geographical distribution, abundant in the neritic plankton of the Ivory Coast (Binet 1977). Although this species was never dominant at Gravelines, in autumn it is regularly abundant, from September until December. In Fig. $5 g$ the marked seasonal variation is evident, but neither a regular year-to-year trend nor segments of homogeneous periods can be seen. The species is omnivorous and even detritivorous. It seems logical to highlight a negative relation between the cumulative deviations of abundance and chlorophyll $\left(\mathrm{r}=-0.566^{\cdots}\right)$ which this species has more or less in common with Euterpina. There was a significant link with nitrates $\left(r=0.238^{*}\right)$.

Group H8: Sagitta setosa (Fig. 5h) showed a clearly recognizable yearly cycle. The geographical distribution of this chaetognath is more coastal (Øresland 1983) than that of Sagitta elegans, which is also considered to be a good descriptor of long-term climatic fluctuations, from the research conducted by Russell $(1935,1936,1939)$ and Southward $(1962,1980,1984)$. This coastal species is widely distributed: it is found in the North Sea and the Channel, as well as in the Mediterranean Sea (Dallot 1978) and the Black Sea (Furnestin 1958). As for Euterpina acutifrons, mentioned previously, the advantage of choosing this species can thus be emphasized for long-term monitoring to compare sites on a large geographical scale. Sagitta setosa is carnivorous, and its predation on the copepod stock, especially Paracalanus parvus, was considerable at Gravelines. The year-to-year evolution (Fig. 5h) showed a 7 yr cycle. This cycle reflected that highlighted for meteorological parameters such as atmospheric temperature (Fromentin \& Ibanez 1994). The correlation calculated on cumulative sums reached $\mathrm{r}=$ $0.551^{\prime *}$ and the Sagitta $/ \mathrm{T}_{\text {water }}=0.425 \cdots$. For the period 1974 to 1982 in the cycle under study, a reverse trend appeared with salinity, but this was no longer a constant relation at the end of the period. On a year-toyear scale, opposition between $S$. setosa and cirriped nauplii could be noted. On the cumulative sums, the correlation cirriped nauplii/Sagitta was $\mathrm{r}=-0.609 *$

\section{DISCUSSION AND CONCLUSION}

Numerical processing of cumulative sums applied to Gravelines plankton time records and of hydroclimatic parameters in the region has enabled cycles to be detected. These cycles are either common to several parameters or biological descriptors or are more specific. The methods used allow data gathered irregu- larly over time to be processed. They provide a useful description of changes which have occurred and reveal the phenomena which often do not stand out on seasonal variation curves. They also report the intervals where correlations between biological and physical processes are very marked. These methods render a plotting approach, such as that for PCA, more heuristic by reinforcing the variance percentage explained by the first principal components (high correlations at the start).

Seven year cycles appeared clearly on the series studied from 1975 to 1992 , both in meteorological parameters such as air temperature and in biological species whose life spans and trophic levels can be very different. These include cirriped larvae, the copepod Temora longicornis, the appendicularian Oikopleura dioica and the chaetognath Sagitta setosa. Therefore, not only did the 7 yr cycle appear for both groups, but a phase opposition between cirriped nauplii and chaetognaths also appeared. This strong relation is of interest; however, it should be noted that the cirriped nauplii group is not homogeneous, but rather made up of larval stages of different species. However, the spring species Balanus balanoides did predominate. Inter-site comparisons remain absolutely indispensable, for this group as for others. In fact most research carried out in the Western Channel, mainly from the Plymouth laboratory, shows that 10 to 11 yr cycles are very important in the ecosystem and are linked to climatic fluctuations (sunspot variation link). However, shorter harmonic cycles also exist (Southward et al. 1975, Colebrook 1982) and this makes it interesting to use the same species over a longer number of years than the period available at Gravelines to compare long-term variations in order to distinguish local phenomena from overall phenomena on a larger spatial scale. Atmospheric pressure and precipitation appeared in 32 mo cycles over the past 50 yr (Fromentin \& Ibanez 1994). Studies of strong winds showed the distinction between anticyclonic periods (characterised by high air temperatures) and cyclic conditions combining west winds and precipitation. The $11 \mathrm{yr}$ cycle shown by the Plymouth data was only seen at Gravelines in the Pseudocalanus minutus group and Oncaea sp. The Gravelines time series was too short to conclude an 11 yr cycle periodicity.

For some years the abrupt changes in parameter values were noted, especially 1979, 1983 and 1986. The instability during 1979 and 1986 was great. During those years, changes occurred for 1 or several parameters. In 1986, an important change took place, and since 1987 a long period of anticyclonic conditions and a rise in temperatures were observed.

Conservative and nonconservative parameters and biological descriptors do not change at the same speed. 
Several cycles can be superimposed (generally 11 yr and 3 to 4 yr). Other authors (Colebrook \& Taylor 1984 , Aebischer et al. 1990) have already observed this in the North Atlantic and the North Sea. Their research, based on a $30 \mathrm{yr}$ time series, would indicate that several cycles lasting 10 to 12,5 to 6 and 3 to 4 yr can be superimposed.

Acknowledgements. The authors acknowledge the assistance received from all involved in sampling surveys, laboratory studies and data analysis since 1975. This work was supported by an 'Electricité de France' contract for the monitoring of French coastal power plants. This work is also part of the PNOC (Programme National d'Océanographie Côtière) research programme's time series topic. We thank Dr C. Parrish and Mrs J. Heard Carnot for comments and help in presenting the manuscript.

\section{LITERATURE CITED}

Aebischer NJ, Coulson JC, Colebrook JM (1990) Parallel long-term trends across four marine trophic levels and weather. Nature 347:753-755

Aminot A, Chaussepied M (1983) Manuel des analyses chimiques en milieu marin. Centre National pour l'Exploitation des Océans. CNEXO, BNDO DOC, Brest

Becker G, Corten AD, Dooley H (1992) Recent high salinity in the English Channel and southern North Sea. Comm Meet int Coun Explor Sea (Hydrography Committee) CM-ICES 1992/C6

Belsher T, Delesmont R, Degros N, Dewarumez JM, Grossel H, Le Fevre-Lehoerff G (1986) Recueil des techniques utilisées pour l'étude écologique des sites de centrales nucléaires, sur les côtes françaises de Manche et Atlantique. DERO-8624-EL, Rapp IFREMER, Brest

Bernard M (1963) Le cycle vital en laboratoire d'un copépode pélagique de Méditerranée: Euterpina acutifrons Claus Pelagos. Bull Inst Oceanogr Alger 1 $35-48$

Beukema JJ (1989) Long-term changes in macrozoobenthic abundance on the tidal flats of the western part of the Dutch Wadden Sea. Helgoländer Meeresunters 43: 405-415

Bhaud MR, Cazaux CP (1990) Buoyancy characteristics of Lanice conchilega (Pallas) larvae (Terebellidae). Implications for settlement. J exp mar Biol Ecol 141:31-45

Binet $\mathrm{D}$ (977) Contributions à la connaissance du zooplancton néritique ivoirien. Ecologie descriptive et dynamique. Thèse Doct es Sciences Naturelles, Univ $P$ et M Curie, Paris VI

Chardy P. Menesguen A (1984) Ecological monitoring and assessment in a coastal power plant impact study: alternative strategy. Thalassia jugosl 20:115-126

Colebrook JM (1981.) Continuous plankton records: persistence in time-series of annual means of abundance of zooplankton. Mar Biol 61:143-149

Colebrook JM (1982) Continuous plankton records: seasonal variations in the distribution and abundance of plankton in the North Atlantic Ocean and the North Sea. J Plankton Res 4:435-462

Colebrook JM (1986) Environmental influences on long-term variabllty in marine plankton. Hydrobiologia 142: $309-325$
Colebrook JM, Taylor AH (1984) Significant time scales of long term variability in the plankton and the environment. Rapp Pv Réun Cons int Explor Mer 183:20-26

Cushing DH (1961) On the failure of the Plymouth herring fishery. J mar biol Ass UK 41:799-816

Cushing DH (1978) Biological effects of climate change. Rapp Pv Réun Cons int Explor Mer 173:107-116

Cushing DH, Dickson RR (1976) The biological response in the sea to climatic changes. Adv mar Biol 14:1-122

Dallot S (1978) Sur la présence du chaetognathe planctonique Sagitta setosa Müller 1897, dans les eaux néritiques de Castellon. Inv Pesq 42:33-52

Dauvin JC, Ibanez F (1986) Variations à long terme (1977-1985) du peuplement des sables fins de la Pierre Noire (Baie de Morlaix, Manche occidentale): analyse statistique de l'évolution structurale. Hydrobiologia 142: $171-186$

Dickson RR (1971) A recurrent and persistent pressure-anomaly pattern as the principal cause of intermediate-scale hydrographic variation in the European shelf seas. Dtsch hydrogr Z 24:97-119

Dickson RR, Meincke J, Malmberg SVA, Lee AJ (1988) The great salinity anomaly in the northern North Atlantic 1968-1982. Prog Oceanogr 20:103-151

Fromentin JM, Ibanez F (1994) Year to year changes in meteorological features of the French coast during the last half century. Examples of two biological responses. Oceanol Acta 17:285-296

Fromentin JM, Ibanez F, Legendre P (1993) A phytosociological method for interpreting plankton data. Mar Ecol Prog Ser 93:285-306

Furnestin ML (1958) Chaetognathes récoltés en Méditerranée orientale et en Mer Noire par la 'Calypso' (campagne 1955). Rapp Pv Réun Comm int Explor scient Mer méditerr 14:202-209

Haq SM (1972) Breeding of Euterpina acutifrons, a harpacticoid copepod with special reference to dimorphic males. Mar Biol 15:221-235

Ibanez F (1984) Sur la segmentation des séries chronologiques planctoniques multivariables. Oceanol Acta $7(4)$ $481-491$

Ibanez F, Etienne $M$ (1992) Le filtrage des séries chronologiques par l'analyse en composantes principales de processus (ACPP). J Rech Océanogr 16:66-72

Ibanez F, Fromentin JM, Castel J (1993) Application de la méthode des sommes cumulées à l'analyse des séries chronologlques en océanographie Cr Acad Sci Paris (Sci Vie) 316:745-748

Lagadeuc Y (1992) Transport larvaire en Manche. Exemple de Pectinaria koreni (Malmgren) annélide polychète en bale de Seine. Oceanol Acta 15(4):383-395

Lamb HH (1969) The new look of climatology. Nature 223: $1209-121.5$

Lamb HH (1985) Climatic history and the future. Princeton University Press, Princeton, NJ

Le Fèvre J, Bourget E (1991) Neustonic niche for crripede larvae as a possible adaptation to long-range dispersal. Mar Ecol Prog Ser 74:185-194

Le Fèvre-Lehoerff G (1985) Technques for zooplankton studies at nuclear power station sites on the English Channel and Atlantic coasts of France. DERO-8712-EL, IFREMER, Brest, p 1-24

Le Fèvre-Lehoerff G, Erard-Le Denn E, Arzul G (1993a) Planktonic ecosystems in the Channel. Trophic relations. Oceanol Acta 1993 16:661-670

Le Fèvre-Lehoerff G, Grossel H, Derrien A (1983) Evolution des populations planctoniques animales en Manche et au 
sud de la Mer du Nord. Proc 17th Eur Mar Biol Symp. Brest, Sept-Oct 1982. Oceanol Acta vol spec:131-135

Le Fèvre-Lehoerff $G$, Grossel $H$, Woehrling $D$, Dewarumez JM, Delesmont R (1993b) La centrale nucléaire littorale de Gravelines: écologie, environnement et impact. J Rech Océanogr 18:33-38

Le Fèvre-Lehoerff G, Quintin JY (1981) Etude comparative de la sensibilité de différentes espèces de copépodes aux variations de la température en Manche. Relations entre la taille des individus et les facteurs du milieu. Influence des rejets thermiques sur le mulieu vivant en mer et en estuaire. In: 2èmes Journées de la Thermoecologie, Nantes, 14-15 nov 1979. EDF Equipement. Actes du Colloque 1:71-86

Le Fèvre-Lehoerff G, Toularastel F, Arnal O (1976) Zooplancton. In: Etude écologique, site de Gravelines. Rapport final, Vol 1. Rapport interne des CNEXO pour EDF, p 105-194

Le Fèvre-Lehoerff G, Woehrling D (1991) Aménagement industriel du littoral et surveillance de l'environnement: la centrale nucléaire de Gravelines (1975 à 1989). Actes du Colloque International sur l'environnement des mers épicontinentales, Lille, 20-22 mars 1990. Oceanol Acta 11 $299-311$

Maddock L, Pingree RD (1982) Mean heat and salts budgets for the eastern English Channel and southern bight of the North Sea. J mar biol Ass UK 62:559-575

Marcaco G (1990) Study of competence and recruitment in Lanice conchilega larvae (Polychaeta Terebellidae). Océanis 16:191-206

Øresland V (1983) Abundance breeding and temporal size distribution of the chaetognath Sagitta selosa in the Kattegat. J Plankton Res 5:425-443

Poulet S (1973) Grazing of Pseudocalanus minutus on naturally occurring particulate matter. Limnol Oceanogr 18 : $564-573$

Poulet S (1974) Seasonal grazing of Pseudocalanus minutus on particles. Mar Biol 25:109-123

Poulet S (1976) Feeding of Pseudocalanus minutus on living and non living particles. Mar Biol 34:117-125

Russell FS (1935) On the value of certain plankton animals as indicators of water movements in the English Channel and North Sea. J mar biol Ass UK 20:309-332

Russell FS (1936) The importance of certain plankton animals as indicators of water movements in the western end of the English Channel. Rapp Pv Cons Perm int Explor Mer 100: $7-10$

This article was submitted to the editor
Russell FS (1939) Hydrographical and biological conditions in the North Sea as indicated by plankton organisms. J Cons int Explor Mer 14:171-192

Russell FS, Southward AJ, Boalch GT, Butler El (1971) Changes in brological conditions in the English Channel off Plymouth during the last half century. Nature 234: $468-470$

Salomon JC, Breton M (1993) An atlas of long term currents in the Channel. Oceanol Acta 1993 16:439-448

Smetacek $V$ (1985) The annual cycle of Kiel Bight plankton: a long term analysis. Fistuaries 8:145-157

Southward AJ (1962) The distribution of some plankton animals in the English Channel and approaches. [l. Surveys with the Gulf. III. High speed sample 1958-1960. J mar biol Ass UK 42:275-375

Southward AJ (1963) The distribution of some plankton animals in the English channel and approaches. III. Theories about long term biological changes including fish. J mar biol Ass UK 43:1-29

Southward A.J (1980) The western English Channel - an inconstant ecosystem? Nature 285:361-366

Southward AJ (1984) Fluctuations in the 'indicator' chaetognaths Sagitta elegans and Sagitta setosa in the western channel. Oceanol Acta 7:229-239

Southward AJ, Butler El, Pennycuick L (1975) Recent cyclic changes in climate and in abundance of marine life. Nature 253:714-717

Taylor AH, Reid PC, Marsh TJ, Jonas TD, Stephens JA (1981) Year to year changes in the salinity of the eastern English channel, 1948-1973: a budget. J mar biol Ass UK 61: $489-507$

Taylor AH, Stephens JA (1983) Seasonal and year to year changes in the temperatures of the English Channel and the southern North Sea, 1961-1976: a budget. Oceanol Acta 6:63-72

Toularastel F, Le Fèvre-Lehoerff G, Arnal O (1977) L'intérêt du zooplancton dans l'élaboration d'un état de référence. Influence des rejets thermiques sur le milieu vivant en mer et en estuaire. In: 1ères Journées de la Thermoécologie, Brest. EDF Equipement. Actes du Colloque 1. $461-480$

Woehrling D, Le Fèvre-Lehoerff G (1993) Fluctuations pluriannuelles de la ponte de la sole Solea solea (L.) sur le littoral du sud de la Mer du Nord. J Rech Océanogr 18:74-79

Wyatt T 11973) The biology of Oikopleura dioica and Fritillaria borealis in the southern bight. Mar Biol 22:137-158

Manuscript first received: December 19, 1994

Revised version accepted: June 26, 1995 